\title{
PERLINDUNGAN HUKUM BAGI KREDITUR DALAM PEMBERIAN KREDIT TANPA AGUNAN
}

\author{
Oleh \\ Agustina Ni Made Ayu Darma Pratiwi SH.,M.Hum \\ Duwi Aprianti, S.H.,M.H. \\ Fakultas Hukum Universitas Mahasaraswati Denpasar, Jalan kamboja \\ Nomor 11A Denpasar
}

\begin{abstract}
This paper aims to identify and analyze legal protection for creditors in providing working capital loans without collateral. The writing method used is normative juridical with a statutory approach. Credit in banking activities is the most important activity, because the largest income from bank business comes from income from credit business activities. Banks provide credit based on trust, so that granting credit is giving trust to customers. But what about credit without collateral because credit collateral will provide legal certainty to the bank that the credit will still return by executing the credit guarantee, while unsecured credit provides no guarantee at all. The basic law that we can use is Articles 1131 and 1132, there are explained in detail about the unsecured credit.
\end{abstract}

Keywords: Legal protection, Personal Loan, creditors, debtors

ABSTRAK, Tulisan ini bertujuan untuk mengetahui dan menganalisis perlindungan hukum bagi kreditor dalam pemberian kredit modal kerja tanpa agunan. Metode penulisan yang digunakan adalah yuridis normatif dengan pendekatan perundangundangan. Kredit dalam kegiatan perbankan merupakan kegiatan yang paling utama, karena pendapatan terbesar dari usaha bank berasal dari pendapatan kegiatan usaha kredit. Bank memberikan kredit didasarkan atas keprcayaan, sehingga pemberian kredit merupakan pemberian kepercayaan kepada nasabah. Namun bagaimana dengan kredit tanpa agunan karena agunan kredit akan memberikan jaminan kepastian hukum kepada pihak perbankan bahwa kreditnya akan tetap kembali dengan cara mengeksekusi jaminan kreditnya sedangkan kredit tanpa agunan tidak memberikan jaminan sama sekali. Secara hukum dasar yang dapat kita gunakan adalah Pasal 1131 dan 1132, disana dijelaskan secara detail mengenai kredit tanpa agunan tersebut.

Kata kunci: Perlindungan Hukum, Kredit Tanpa Agunan, kreditor, debitor

\section{A. Pendahuluan}

Pembangunan nasional merupakan upaya pembangunan yang berkesinambungan dalam rangka mewujudkan masyarakat Indonesia yang adil dan makmur berdasarkan Pancasila dan Undang-Undang Dasar 1945, dalam menghadapi perkembangan perekonomian nasional yang senantiasa bergerak cepat, kompetitif, dan terintegrasi dengan tantangan yang semakin kompleks serta sistem keuangan yang semakin maju, diperlukan penyesuaian kebijakan di bidang ekonomi, termasuk perbankan sehingga diharapkan akan dapat memperbaiki dan memperkukuh perekonomian nasional ${ }^{1}$ Sektor Perbankan yang memiliki posisi strategis sebagai lembaga intermediasi dan penunjang merupakan faktor yang sangat menentukan dalam proses penyesuaian dimaksud. Sehubungan dengan itu, diperlukan penyempurnaan terhadap sistem Perbankan nasional yang bukan hanya mencakup upaya penyehatan bank secara individual melainkan juga penyehatan sistem Perbankan secara menyeluruh. Upaya penyehatan Perbankan nasional menjadi

\footnotetext{
${ }^{1}$ Undang-Undang No 10 Tahun 1998 tentang perubahan atas Undang-Undang No 7 Tahun 1992 Tentang Perbankan
} 
tanggung jawab bersama antara Pemerintah, bank-bank itu sendiri dan masyarakat pengguna jasa bank. Adanya tanggung jawab bersama tersebut dapat membantu memelihara tingkat kesehatan Perbankan nasional sehingga dapat berperan secara maksimal dalam perekonomian nasional.

Peranan Perbankan nasional perlu ditingkatkan sesuai dengan fungsinya dalam menghimpun dan menyalurkan dana masyarakat dengan lebih memperhatikan pembiayaan kegiatan sektor perekonomian nasional dengan prioritas kepada koperasi, pengusaha kecil dan menengah, serta berbagai lapisan masyarakat tanpa diskriminasi sehingga akan memperkuat struktur perekonomian nasional, demikian pula bank perlu memberikan perhatian yang lebih besar dalam meningkatkan kinerja perekonomian di wilayah operasi tiap-tiap kantor. ${ }^{2}$

Di Indonesia peranan perbankan dalam hal sumber pembiayaan dunia masih sangat dominan. Bank sebagai lembaga keuangan hadir ditengahtengah masyarakat untuk menyalurkan dana yang diperoleh dari masyarakat dan dikembalikan lagi kepada masyarakat dalam bentuk kredit. Kredit dalam kegiatan perbankan adalah kegiatan usaha yang paling utama, karena pendapatan terbesar dari usaha bank adalah pendapatan yang berasal dari kegiatan usaha kredit yaitu bunga dan provisi. Fungsi utama bank adalah sebagai wahana yang dapat secara optimal menghimpun dana dan selanjutnya secara selektif menyalurkan dana tersebut dalam bentuk kredit kepada para pengusaha sebagai pelaku usaha dan pelaku bisnis yang membutuhkannya. Pihak bank dalam hal ini bank milik negara ataupun bank yang

2 Penjelasan Undang-Undang No 10 Tahun 1998 Tentang Perubahan Undang-Undang No 7 Tahun 1992 tentang Perbankan dikelola oleh pihak swasta sebagai salah satu insan perbankan nasional berusaha untuk membantu kesulitan dana yang dialami oleh para pengusaha sebagai pelaku bisnis. ${ }^{3}$ Fungsi utama bank adalah sebagai wahana yang dapat secara optimal menghimpun dana dan selanjutnya secara selektif menyalurkan ana tersebut dalam bentuk kredit kepada paraFungsi utama bank adalah sebagai wahana yang dapat secara optimal menghimpun dana dan selanjutnya secara selektif menyalurkan dana tersebut dalam bentuk kredit kepada paraFungsi utama bank adalah sebagai wahana yang dapat secara optimal menghimpun dana dan selanjutnya secara selektif menyalurkan dana tersebut dalam bentuk kredit kepada paraFungsi utama bank adalah sebagai wahana yang dapat secara optimal menghimpun dana dan selanjutnya secara selektif menyalurkan dana tersebut dalam bentuk kredit kepada para

Salah satu kegiatan yang dapat diberikan oleh bank baik itu bank milik negara maupun bank swasta yaitu kegiatan pinjam meminjam uang. Kegiatan pinjam meminjam uang sudah ada sejak lama dalam kehidupan masyarakat yang telah mengenal uang sebagai alat pembayaran, hampir seluruh masyarakat telah menjadikan kegiatan pinjam meminjam uang sebagai sesuatu yang sangat diperlukan untuk mendukung perkembangan kegiatan perekonomiannya dan untuk meningkatkan taraf kehidupannya. Bila ditinjau dari sudut perkembangan perekonomian nasional dan internasional akan dapat diketahui betapa besar peranan yang terkait dengan kegiatan pinjam meminjam uang pada saat ini. Berbagai lembaga

\footnotetext{
${ }^{3}$ Muhammad Hatta, Implementasi Perlindungan Hukum Bagi Kreditor Dalam Pemberian Kredit Modal Kerja Tanpa Agunan ARENA HUKUM Volume 7, Nomor 1, April 2014, Hal 27
} 
keuangan terutama bank konvensional telah membantu pemenuhan kebutuhan dana bagi kegiatan perekonomian ngan memberikan pinjaman uang antara lain dalam bentuk kredit perbankan. Kredit perbankan merupakan salah satu usaha bank konvensional yang telah banyak dimanfaatkan oleh masyarakat yang memerlukan dana. ${ }^{4} \backslash$

$$
\text { Kredit dalam kegiatan }
$$

perbankan merupakan kegiatan yang paling utama, karena pendapatan terbesar dari usaha bank berasal dari pendapatan kegiatan usaha kredit. Lembaga keuangan dalam dunia keuangan bertindak sebagai lembaga penyedia jasa keuangan bagi nasabahnya, yang mana pada umumnya lembaga ini diatur oleh regulasi keuangan dari pemerintah. Penyaluran yang dilakukan kepada masyarakat terutama untuk pengusaha kecil dan ekonomi lemah merupakan kebijakan dari sektor perbankan. Penyaluran dana dapat dilakukan melalui pemberian kredit dengan syarat-syarat yang telah ditentukan, salah satunya adalah jaminan untuk meminjam kepastian pelunasan hutang dari debitur kepada kreditur bilamana dikemudian hari melakukan wanprestasi atau ingkar janji. Sebetulanya pemberian kredit yang aman bagi kreditur adalah dengan memberikan kredit yang menggunakan jaminan atau agunan. Benda yang paling sering digunakan untuk jaminan atau agunan adalah tanah dalam pemberian fasilitas kredit, karena tanah pada umumnya tanah mudah dijual dan mempunyai nilai jual tinggi dibandingkan dengan benda selain tanah, dan tentunya tanah dapat dibebani dengan hak tanggungan.

\footnotetext{
${ }^{4}$ Bahsan, hukum jaminan dan jaminan kredit perbankan Indonesia, Jakarta :raja grafindo persada 2007. hal 2
}

Bank memberikan kredit didasarkan atas keprcayaan, sehingga pemberian kredit merupakan pemberian kepercayaan kepada nasabah. Pemberian kredit ini merupakan salah satu cara bank untuk memperoleh keuntungan, maka bank hanya boleh meneruskan simpanan masyarakat kepada nasabahnya dalam bentuk kredit jika betul-betul yakin bahwa debitur akan mengembalikan pinjaman yang diterimanya sesuai dengan jangka waktu dan syarat-syarat yang telah disetujui oleh kedua belah pihak. Seiring perkembangan jaman pemberian kredit mengalami perubahan yang begitu pesat banyaknya kebutuhan masyarakat sehingga membuat pemerintah untuk mengeluarkan kebijakan dibidang keuangan dan bank-bank pun baik lokal maupun asing memberikan berbagai macam kredit seperti kredit dengan agunan ataupun tanpa agunan. Kemudian muncul permasalahan bagaimana perlindungan hukum kreditur dengan kredit tanpa agunan tersebut. Oleh sebab itu penulis akan membahas bagaimana perlindungan hukum Kredit Tanpa Agunan (KTA) tersebut.

Berdasarkan uraian latar belakang masalah di atas, makan dapat dirumuskan permasalahan yang akan menjadi pokok pembahasan, adalah bagaimanakah perlindungan hukum bagi kreditur dalam pemberian kredit tanpa agunan?

Adapun tujuan penulisan ini
adalah Untuk mengetahui dan
menganalisis perlindungan hukum bagi
kreditor dalam pemberian kredit modal
kerja tanpa agunan.

\section{B. Pembahasan}

\section{Penjelasan Kredit Tanpa Agunan}

Kata "Kredit" berasal dari bahasa Yunani "credere" yang berarti kepercayaan dengan demikian istilah kredit memiliki arti khusus, yaitu meminjamkan uang (atau penundaan 
pembayaran). Unsur kepercayaan dalam hal ini adalah keyakinan dari pemberi kredit bahwa prestasi yang diberikannya baik dalam bentuk uang, barang, atau jasa akan benar-benar diterimanya kembali dalam jangka waktu tertentu di masa yang akan datang. ${ }^{5}$ Apabila dihubungkan dengan bank, maka terkandung pengertian bahwa bank selaku kreditor percaya meminjamkan sejumlah uang kepada nasabah atau debitor yang dapat dipercaya kemampuannya untuk membayar lunas pinjamannya setelah jangka waktu yang ditentukan. Menurut Pasal 1 ayat (12) Undang - Undang Nomor 7 Tahun 1992, kredit adalah penyediaan uang atau tagihan yang dapat dipersamakan dengan itu. Berdasarkan persetujuan atau kesepakatan pinjam-meminjam antara bank dengan pihak lain yang mewajibkan pihak peminjam untuk melunasi hutangnya setelah jangka waktu tertentu dengan jumlah bunga imbalan atau pembagian hasil keuntungan. Setelah itu pengertian Agunan menurut Undang-Undang Perbankan ialah kemampuan, keyakinan atau kesanggupan nasabah untuk melunasi kewajibannya sesuai dengan yang dijanjikan. Selain itu pak Widiyono mengatakan bahwa Agunan yaitu suatu benda bergerak ataupun benda tidak bergerak yang diserahkan debitur kepada kreditur yang berguna untuk menjamin apabila terjadi kondisi dimana fasilitas kredit tidak bisa dibayar kembali sesuai waktu yang telah ditetapkan. ${ }^{6}$ Sehingga dapat disimpulkan bahwa Kredit Tanpa Agunan adalah sebuah produk perbankan yang memberikan fasilitas pinjaman kepada peminjam tanpa adanya sebuah agunan

\footnotetext{
5 Thomas Suyatno, dkk, Dasar-dasar

Perkreditan, Jakarta: PT. Gramedia Pustaka

Utama, 1997, hlm. 14

${ }^{6}$ https://sarjanaekonomi.co.id/pengertianagunan/\#Pengertian_Agunan diakses pada tanggal 16 Agustus 2020 pukul. 10.51
}

yang dijadikan jaminan atas pinjaman tersebut. Pengertian tersebut dapat dijelaskan bahwa seorang debitur meminjam uang kepada pihak bank tanpa adanya jaminan hanya bermodalkan kepercayaan. Memang resikonya lebih besar tetapi pihak bank tidak sembarangan memberikan pinjaman tentunya harus melalui persyaratan yang ketat.

Sebagaimana telah dijelaskan di atas, jika dilihat dari segi jaminannya kredit dapat dibedakan menjadi kredit dengan jaminan dan kredit tanpa jaminan. Seperti yang telah dijelaskan sebelumnya Kredit tanpa jaminan atau Kredit Blanko (unsecured loan) yaitu pemberian kredit tanpa jaminan material (agunan fisik), pemberiannya sangatlah selektif dan ditujukan kepada nasabah besar yang telah teruji bonafiditas, kejujuran dan ketaatannya dalam transaksi perbankan maupun kegiatan usaha yang dijalaninya. Dalam Peraturan Perundang-Undangan yang berlaku seperti Undang-Undang Nomor 7 Tahun 1992 tentang Perbankan, pemberian kredit demikian dapat saja direalisasikan, sebab PerundangUndangan Perbankan yang berlaku sekarang lebih menganut kepada jaminan yang bersifat non fisik, artinya bahwa pemberian kredit dapat dilakukan oleh bank apabila bank mempunyai keyakinan terhadap debitur atas kemampuan, dan kesanggupan debitur untuk melunasi hutangya sesuai dengan yang diperjanjikan. Kredit tanpa jaminan mengandung lebih besar resiko, sehingga dengan demikian berlaku bahwa semua harta kekayaan debitur baik yang bergerak maupun tidak bergerak yang sudah ada maupun yang akan ada kemudian seluruhnya menjadi jaminan pemenuhan pembayaran hutang. Bagi dunia Perbankan, Kredit tanpa jaminan merupakan jenis kredit yang mengandung resiko besar, oleh karenanya tidak banyak bank di Indonesia yang mengeluarkan kredit 
jenis ini. Bank sebagai suatu lembaga penghimpun dana dari dan untuk masyarakat akan menerapkan Prinsip Kehati-hatian Bank dalam setiap pemberian kredit kepada nasabah (debitur). Berlatar-belakang prinsip tersebut banyak Bank mengeluarkan kredit kepada nasabah (debitur) dengan jalan meminta jaminan atau yang dikenal dengan Kredit dengan Jaminan, sebagai salah satu cara meminimalisir resiko kerugian yang akan diderita sebagai akibat nasabah (debitur) tidak dapat melunasi kreditnya sesuai dengan yang telah diperjanjikan. ${ }^{7}$

\section{Penerapan Prinsip Kehatian- Hatian dalam Pemberian Kredit Tanpa Agunan}

Pemberian kredit dapat diberikan oleh lembaga keuangan perbankan maupun lembaga keuangan non-perbankan, namun demikian untuk lembaga perbankan pemberian kredit dilakukan berdasarkan syarat-syarat yang cukup sulit. Akan tetapi ada beberapa bank swasta yg memberikan syarat yang mudah, Pemberian kredit tersebut terkesan sangat mudah bahkan tidak jarang terkesan sangat dipaksakan karena dalam pencairan kredit kepada masyarakat tersebut tidak melalui suatu penelitian yang mendalam yang tentunya juga membutuhkan waktu baik administrasi maupun dalam mengambil kesimpulan sebelum mencairkan kredit.

Berkaitan dengan prinsip pemberian kredit oleh bank kepada debitur berpedoman kepada 2 prinsip yaitu : ${ }^{8}$

1. Prinsip Kepercayaan

Pemberian kredit oleh bank kepada nasabah debitor selalu didasarkan kepada kepercayaan. Bank mempunyai

7 Ni Made Arini dkk, Penyelesaian permasalahan kredit tanpa agunan (umkm) di Denpasar, jurnal ilmiah prodi magister kenot ariatan, 2016 - 2017 halaman 125

${ }^{8}$ Hermansyah. Hukum Perbankan Nasional

Indonesia. Jakarta.Kencana. 2011. Hal 64-65 kepercayaan bahwa kredit yang diberikannya bermanfaat bagi nasabah debitor sesuai dengan peruntukannya yang bersangkutan mampu melunasi utang kredit beserta bunga dalam jangka waktu yang telah ditentukan.

2. Prinsip Kehati-hatian (Prudential Principle)

Bank dalam menjalankan kegiatan usahanya, termasuk pemberian kredit kepada nasabah debitor harus selalu berpedoman dan menerapkan prinsip kehati-hatian. Prinsip ini antara lain diwujudkan dalam bentuk penerapan secara konsisten berdasarkan iktikad baik terhadap semua persyaratan dan peraturan perundang- undangan yang terkait dengan pemberian kredit oleh bank bersangkutan. Prinsip kehati-hatian atau yang dalam istilah lain disebut dengan banking prudential principles merupakan prinsip yang umum yang digunakan dalam kegiatan atau aktivitas perbankan. Salah satunya adalah melalui pengawasan, yakni sampai sejauh mana bank diawasi kegiatan dengan menggunakan prinsip kehati-hatian sebagai tolok ukur utama. Namun, pengawasan perbankan pada umumnya merupakan tindakan represif yang tidak cukup mencegah terjadinya kebangkrutan bank atau likuidasi atau pembekuan kegiatan usaha dan ditempatkannya bank dalam pengawasan khusus di masa industri perbankan di tahun 2004. Bahkan bankbank tersebut bangkrut karena "dirampok" oleh pemilik dan atau pengurusnya sendiri dan pengawas "terlambat" mengetahuinya. Beberapa studi memang meragukan efektifitas aturan kehati-hatian (prudential regulation) dan kinerja lembaga pengawas. Pendekatan alternatif yang ditawarkan adalah menerapkan sunshine regulation (aturan keterbukaan). Tujuannya adalah untuk meningkatkan kemampuan nasabah dan stakeholder lainnya mengawasi bank secara 
langsung. ${ }^{9}$ Aspek keterbukaan yang dilakukan perbankan menjadi bagian yang tidak terpisahkan dalam setiap aktivitas perbankan di Indonesia

Untuk mencegah terjadinya kredit bermasalah dikemudian hari, penilaian suatu bank untuk memberikan persetujuan terhadap suatu permohonan kredit dilakukan dengan berpedoman kepada Formula 4P dan 5C.

diuraikan sebagai berikut ${ }^{10}$ :

$$
\text { Formula 4P dapat }
$$

a. Personality

Pihak Bank mencari data secara lengkap mengenai kepribadan si pemohon kredit, antara lain mengenai riwayat hidupnya, pengalamannya, dan lain- lain. Hal ini diperlukan untuk menentukan persetujuan kredit yang diajukan oleh pemohon kredit.

b. Purpose

Selain mengenai kepribadian (personality) dari pemohon kredit, bank juga harus mencari data tentang tujuan atau penggunaan kredit tersebut sesuai lineof business kredit bank yang bersangkutan.

c. Prospect

Bank harus melakukan analisis secara cermat dan mendalam tentang bentuk usaha yang akan dilakukan oleh pemohon kredit. Misalnya, apakah usaha yang dijalankan oleh pemohon kredit mempunyai prospek di kemudian hari ditinjau dari aspek ekonomi dan kebutuhan masyarakat.

d.

$$
\text { Payment }
$$

Bank harus mengetahui dengan jelas mengenai kemampuan dari

9 Zulkarnain Sitompul, Transparansi Perbankan: Tantangan 2005. Pilars N0.51/TH VII/27 Desember 2004-09 Januari 2005. h. 1

${ }^{10}$ Gendhis G, Analisis Hukum Kredit Tanpa Agunan (KTA) Mandiri Payroll dan Non

Payroll, Bandar Lampung: 2019 hal 10-11 pemohon kredit untuk melunasi utang kredit dalam jumlah dan jangka waktu yang ditentukan.

Mengenai Formula 5C dapat diuraikan sebagai berikut :

a. Character, bahwa calon nasabah debitor memiliki watak, moral,dan sifat-sifat pribadi yang baik.penilaian terhadap karakter ini dilakukan untuk mengetahui tingkat kejujuran, integritas, dan kemauan dari calon nasabah debitor untuk memenuhi kewajiban dan menjalankan usahanya

b. Capacity, kemampuan calon nasabah debitor untuk mengelola kegiatan usahanya dan mampu melihat prospektif masa depan, sehingga usahanya akan dapat berjalan dengan baik dan memberikan kentungan, yang menjamin bahwa ia mampu melunasi hutang kreditnya dalam jumlah dan jangka waktu yang ditentukan

c. Capital, bank harus terlebih dahulu melakukan penelitian terhadap modal yang dimiliki oleh pemohon kredit

d. Colleteral adalah jaminan untuk persetujuan pemberian kredit yang merupakan sarana pengaman (back up) atas resiko yang mungkin terjadi atas wanprestasinya nasabah debitor di kemudian 
hari, misalnya terjadi kredit macet.

e. Condition of Economic Bahwa dalam pemberian kredit oleh bank, kondisi ekonomi secara umum dan sektor usaha pemohon kredit perlu memperoleh perhatian dari bank untuk memperkecil risiko yang mungkin terjadi yang diakibatkan oleh kondisi ekonomi tersebut.

Fungsi utama bank adalah sebagai wahana

yang dapat secara optimal menghimpun dana

dan selanjutnya secara selektif

menyalurkan

dana tersebut dalam bentuk kredit

kepada

\section{Perlindungan bagi kreditur dalam memberikan Kredit Tanpa Agunan (KTA)}

Agunan sebagai salah satu unsur pemberian kredit, maka apabila berdasarkan unsur-unsur lain dapat diperoleh keyakinan atas kemampuan nasabah debitur mengembalikan utangnya, agunan dapat hanya berupa barang, proyek atau hak tagih yang dibiayai dengan kredit yang bersangkutan. Dalam Pasal 1 angka 23 Undang-Undang Perbankan mengatur mengenai pengertian agunan. Agunan adalah jaminan tambahan yang diserahkan nasabah debitur kepada bank dalam rangka pemberian fasilitas kredit atau pembiayaan berdasarkan prinsip Syariah. ${ }^{11}$ Pengertian agunan di atas, dapat dijelaskan bahwa fungsi utama dari jaminan adalah untuk meyakinkan bank agar melunasi kredit yang diberikan kepada debitur sesuai dengan

\footnotetext{
${ }^{11}$ H R Daeng Naja, Hukum Kredit dan Bank Garansi, PT Citra Aditya Bakti, Bandung, 2005, hlm 208
}

perjanjian kredit yang telah disepakati bersama. Agunan kredit akan memberikan jaminan kepastian hukum kepada pihak perbankan bahwa kreditnya akan tetap kembali dengan cara mengeksekusi jaminan kreditnya dan sesuai dengan gambaran diatas bahwa agunan dalam prakteknya lebih dipentingkan dalam pemberian kredit ini, sehingga tidak berlebihan apabila bank memandang perlu dalam rangka menambah keyakinan atas watak dan kemampuan debitur, bank selalu meminta jaminan pemberian kredit dari pihak lain seperti jaminan pribadi, garansi dari bank lain atau jaminan dari induk perusahaan.

Persoalan agunan ini berkaitan dengan ketentuan pasal 1131 dan 1132 Kitab Undang-undang Hukum Perdata. Kedua pasal ini membahas tentang piutang- piutang yang diistimewakan. Pasal 1131 KUHPer mengatakan bahwa segala kebendaan si berutang, baik yang bergerak maupun tidak bergerak, baik yang sudah ada maupun yang baru akan ada dikemudian hari, menjadi tanggungan untuk segala perikatan perseorangan. Dan pasal 1132 mengatakan bahwa kebendaan tersebut menjadi jaminan bersama-sama bagi semua orang yang mengutangkan padanya, pendapatan penjualan bendabenda itu dibagi-bagikan menurut keseimbangan, yaitu menurut besarkecilnya piutang masing-masing, kecuali apabila diantara para piutang itu ada alasan-alasan yang sah untuk didahulukan.

Untuk kredit tanpa agunan, karena pihak bank tidak menentukan dari awal apa yang menjadi agunannya dan dalam hal ini memang tidak menggunakan agunan, maka berdasarkan pasal 1131 dan 1132 KUHPer, harta kekayaan milik dari debitur seluruhnya menjadi jaminan terhadap jumlah utang yang harus dibayarkan oleh debitur. Akibatnya jika terjadi wanprestasi dari pihak debitur, 
maka pihak Bank melakukan eksekusi berdasarkan pasal 1131 dan 1132 KUHPer. Dengan menggunakan kedua pasal tersebut pihak kreditor melakukan penilaian terhadap nilai ekonomi seluruh harta maupun barang-barang berharga milik debitur yang wanprestasi sebagai pelunasan dari sisa prestasinya yang belum terpenuhi. ${ }^{12}$

Dalam dunia perbankan sering kali terjadi permasalahan-permasalahan yang nantinya akan terdapat implikasi hukum bagi para pelaku yang bersangkutan. Salah satu di Antara permasalahan yang sering terjadi ialah bagaimana sistem kredit yang tidak menggunakan agunan maupun jaminan dan bagaimana perlindungan hukumnya, Jaminan dari pihak debitur merupakan persyaratan mutlak dengan tujuan untuk adanya kepastian hukum yang secara tegas telah diatur dalam perjanjian kredit. Hal ini disebabkan karena jaminan merupakan hal yang sangat penting bagi pihak bank untuk menangkal resiko-resiko yang mungkin akan timbul di kemudian hari sebagai akibat dari pemberian kredit oleh bank kepada pihak debitur.

\section{Kesimpulan}

Berdasarkan analisis yang sudah dibahas dalam pembahasan di atas dapat disimpulkan bahwa perlindungan hukum bagi kreditur dalam pemberian kredit tanpa agunan berdasarkan pasal 1131 dan 1132 Kitab Undang-Undang Hukum Perdata harta kekayaan milik dari debitur seluruhnya menjadi jaminan terhadap jumlah utang yang harus dibayarkan oleh debitur. Akibatnya jika terjadi wanprestasi dari pihak debitur, maka pihak Bank melakukan eksekusi berdasarkan pasal 1131 dan 1132 KUHPer. Dengan menggunakan kedua pasal tersebut pihak kreditor melakukan penilaian terhadap nilai ekonomi seluruh

\footnotetext{
${ }^{12}$ Muhammad H, Perlindungan Hukum Bagi Kreditor Dalam Pemberian Kredit Modal Kerja Tanpa Agunan, Samarinda.hal 11
}

harta maupun barang-barang berharga milik debitur yang wanprestasi sebagai pelunasan dari sisa prestasinya yang belum terpenuhi.

\section{Saran.}

1. Perlu adanya sosialisasi mengenai Kredit Tanpa Agunan (KTA) dengan kaitannya Pasal 1131dan 1132 KUHPer kepada pihak debitur.

2. Apabila debitur melakukan wanprestasi maka penyelesaiannya utamanya melalui jalur non litigasi apabila dibisa terselesaikan maka dapat diambil jalur litigasi.

\section{DAFTAR PUSTAKA \\ Undang-Undang}

Undang-Undang No 10 Tahun 1998

tentang perubahan atas Undang-Undang No 7 Tahun 1992 Tentang Perbankan

Penjelasan Undang-Undang No 10 Tahun $1998 \quad$ Tentang Perubahan Undang-Undang No 7 Tahun 1992 tentang Perbankan

\section{Buku}

Bahsan, hukum jaminan dan jaminan kredit perbankan Indonesia, Jakarta :raja grafindo persada 2007. hal 2

Gendhis G, Analisis Hukum Kredit Tanpa Agunan (KTA) Mandiri Payroll dan Non Payroll, Bandar Lampung: 2019 hal 10-11

H R Daeng Naja, Hukum Kredit dan Bank Garansi, PT Citra Aditya Bakti, Bandung, 2005, hlm 208

Hermansyah. Hukum Perbankan

Nasional Indonesia. Jakarta.Kencana. 2011. Hal 64-65

Muhammad H, Perlindungan Hukum Bagi Kreditor Dalam Pemberian Kredit Modal Kerja Tanpa Agunan, Samarinda.hal 11 
Muhammad Hatta, Implementasi Perlindungan Hukum Bagi Kreditor Dalam Pemberian Kredit Modal Kerja Tanpa Agunan, ARENA HUKUM Volume 7, Nomor 1, April 2014, Hal 27

$\mathrm{Ni}$ Made Arini dkk, Penyelesaian permasalahan kredit tanpa agunan (umkm) di Denpasar, Jurnal ilmiah prodi magister kenot ariatan, 2016 - 2017 halaman 125

Thomas Suyatno, dkk, Dasar-dasar Perkreditan, Jakarta: PT. Gramedia Pustaka Utama, 1997, hlm. 14
Zulkarnain Sitompul, Transparansi Perbankan: Tantangan 2005. Pilars N0.51/TH VII/27 Desember 2004-09 Januari 2005. h. 1

Website.

https://sarjanaekonomi.co.id/pengertianagunan/\#Pengertian_Agunan diakses pada tanggal 16 Agustus 2020 pukul. 10.51 